\title{
Improvement of Tensile Strength of Viscose Woven Fabric by Applying Chemical Finishes
}

\author{
Mahbubur Rahman, A. K. M. Ayatullah Hosne Asif ${ }^{*}$, Priti Sarker, Bappi Sarker \\ Department of Textile Engineering, Mawlana Bhashani Science and Technology University, Bangladesh
}

Received August 17, 2019; Revised November 11, 2019; Accepted November 18, 2019

Copyright $\mathrm{C} 2019$ by authors, all rights reserved. Authors agree that this article remains permanently open access under the terms of the Creative Commons Attribution License 4.0 International License

\begin{abstract}
This research work was endeavored to improve tensile strength of viscose woven fabric by using chemical finishes like water repellent finishes with cross linking agent and softener. In this work, $100 \%$ viscose woven fabric was used and different types of samples were prepared by treating water repellent finishes, cross linking agent and softeners. The sample was investigated by tensile strength test (ASTM D5034), spray test (AATCC-22), water vapor test (cup method) and moisture regain test (ASTM D2495 oven dry method). Eight types of recipes were used in this research. For the variation of $\mathrm{C}_{6}$-fluorocarbon the sample code- $\mathrm{B}\left(\mathrm{C}_{6}\right.$-fluorocarbon 60 $\mathrm{g} / 1$, cross-linking agent $15 \mathrm{~g} / 1$ and softener $10 \mathrm{~g} / \mathrm{l}$ ) showed better result in tensile strength and water spray test. Taking the amount of $\mathrm{C}_{6}$-fluorocarbon $(60 \mathrm{~g} / \mathrm{l})$ as constant and making variation cross linking agent which reached a conclusion that, sample-B1 $\left(\mathrm{C}_{6}\right.$-fluorocarbon $60 \mathrm{~g} / \mathrm{l}$, cross-linking agent $05 \mathrm{~g} / 1$ and softener $10 \mathrm{~g} / 1)$ showed better result for wet tensile strength, water spray test and moisture regain but showed less water vapor permeability. From this experiment it was evident that recipe which belongs to sample code B1 is suitable for improving the tensile strength of viscose fabric.
\end{abstract}

Keywords Viscose, Cross Linking Agent, Moisture Regain, Softener, Tensile Strength

\section{Introduction}

From textiles point of view, cotton and viscose both are important cellulosic fibers mostly used in modern textile manufacturing industry [1]. Viscose is a very important regenerated cellulosic fiber largely employed in textiles and clothing manufacturing industry [2]. Recently, there is a new beginning for viscose made up of cellulose, a constituent of all land growing vegetation. A spread of dissolving grade wood pulps are employed as cellulose supply to give viscose rayon [3]. Cellulose based mostly, viscose is meant to provide a solution to the steady increasing issues of upper world market cotton costs higher demand for fibers, as well as a chase for brand new fiber material supply and a requirement for a broadening of the marketplace for wood and pulp [4]. Technically three generations of regenerated cellulose fibres, such as viscose, modal, bamboo and tencel fibres are among the significant fibres from the point of textile and environmental aspects due to the natural structures and properties [5]. Different production process and production conditions related to conventional viscose, modal, bamboo and new tencel fibres cause differences in the construction of the fibres in spite of the same chemical compositions [6].

Viscose fibers with improved wet strength and improved elastic recovery referred to as High Wet Modulus viscose fibers (HMW). The properties of those fibers represent the same because the regular viscose fiber (however lower water absorption), additionally to high wet strength [7]. These fibers square measure usually mixed with cotton fibers. They stand most cotton finishing processes as for instance mercerization. Clothing produced by HMV fiber performs like cotton and might be machine-washed with none severe shrinkage [8].

Viscose has the tendency to soak up higher wet [9]. The applied hydrophobic water repellent finishes was applied to water repellency that was to blame for the rising the wet strength of viscose material [10]. Water-resistant treatment helped in reducing the molecular barrier round the individual fibers that lowered down the crucial physical phenomenon of the fibers [11]. This reduced physical phenomenon of viscose material helped in raising its wet strength [12].

On the standard quality of garment, notably the special barrier item of clothing, the physiological properties have resolutely influenced, that outline comfort and protection functions $[13,14]$. From the thermal comfort point of view, adequate barrier are needed to confirm a physiological comfort, guaranteeing well-being of the user, maintaining the flexibility of perception and reaction rate within the course of their work $[15,16]$. Firemen, medical rescuers or 
the troops activity activities associated with their profession have to be compelled to be sufficiently physically and mentally active while not looking on the parameters of the external surroundings $[17,18]$. They feel surprise if their quality of clothing is appropriate protecting barrier, or whether or not their health and lives are vulnerable in how, because of inappropriate dresses $[19,20]$. Contrary to ordinarily accepted theories protecting clothes, because of sweat natural process or as a result of wet, rainy climate area unit usually employed in wet state that has influence on their comfort properties [21,22]. Therefore, technically this work is a novel work about the improvement of wet tensile strength of viscose woven fabric by application of different types of chemical finishes.

\section{Methodology}

\subsection{Materials}

\subsubsection{Fabric}

In this experiment, $100 \%$ Viscose scoured and bleached woven fabric was used, which was collected from SRG APPAREL PLC, Gulshan 1, Dhaka, Bangladesh. The specification of $100 \%$ Viscose Woven fabric is given below.

Description: $100 \%$ viscose $\mathrm{S} / \mathrm{D}$

Construction: $(45 \times 45) /(110 \times 80) \times 48$

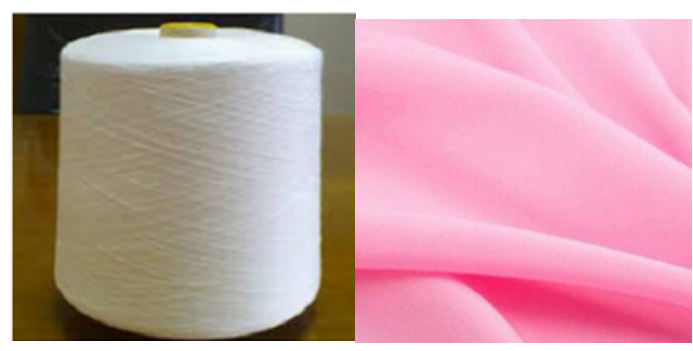

Figure 1. Viscose yarn and woven fabric

\subsection{2. $\mathrm{C}_{6}$-Fluorocarbon (FC)}

"RUCOSTAR EEE6" was used as $\mathrm{C}_{6}$-fluorocarbon. This $\mathrm{C}_{6}$-Fluorocarbon resin enriched with polymeric, hyper branched dendrimers in a hydrocarbon matrix. Basically it is cationic nature. It is free of perfluorooctanoic acid that is perfluorooctane sulfonic acid and alkyl-phenol ethoxylate. Properties of RUCOSTAR EEE6 has some special benefits like, it confers resistance to aqueous and oily soilings, highly resistant to washing, better abrasion resistance than previous fluorocarbon finishes, confers a soft, full handle, not suitable for optically brightened white goods ,no high curing temperatures necessary.

\subsubsection{Softener}

"RUCOFIN HSF" was used as softener. It is polysiloxane compound and non-ionic/weakly cationic nature.

\subsubsection{Wetting Agent}

"RUCOWET VL" was used as wetting agent. It is prepared from fatty alcohol alkoxylate and organic phosphorous compound. This wetting agent is non-ionic nature.

\subsubsection{Cross-Linking Agent}

"RUCO-LINK RCX" was used as cross-linking agent. It is prepared from N-methyloldihydroxyethylene urea. It is non-ionic nature.

\subsection{Preparation of Sample}

At first, $100 \%$ viscose woven fabrics were cut with a dimension of 12 inch $\times 12$ inch. The solution was prepared according to the recipe and used $\mathrm{M}: \mathrm{L}=1: 15$. The samples were passed through the solution with the help of a padding machine. After that the samples were passed through two nip rollers to squeeze out excess solution, leaving the fabric with a certain amount of the chemical finish. At that time padder pressure was 2 bars. Then the samples were dried at $130^{\circ} \mathrm{C}$ for 5 minutes. At last the samples were cured at $150^{\circ} \mathrm{C}$ for 2 minutes.

Table 1. Identification of different types of specimens

\begin{tabular}{|c|l|}
\hline Sample code & Sample type \\
\hline $\mathrm{U}$ & Untreated \\
\hline $\mathrm{A}$ & $\mathrm{C}_{6}$-fluorocarbon $(40 \mathrm{~g} / \mathrm{l})$ \\
\hline $\mathrm{B}$ & $\mathrm{C}_{6}$-fluorocarbon $(60 \mathrm{~g} / \mathrm{l})$ \\
\hline C & $\mathrm{C}_{6}$-fluorocarbon $(80 \mathrm{~g} / \mathrm{l})$ \\
\hline A1 & Sample treated with $\mathrm{RCX}(0 \mathrm{~g} / 1)$ \\
\hline B1 & Sample treated with $\mathrm{RCX}(5 \mathrm{~g} / 1)$ \\
\hline C1 & Sample treated with $\mathrm{RCX}(10 \mathrm{~g} / 1)$ \\
\hline D1 & Sample treated with $\operatorname{RCX}(15 \mathrm{~g} / 1)$ \\
\hline E1 & Sample treated with $\operatorname{RCX~}(20 \mathrm{~g} / 1)$ \\
\hline
\end{tabular}

Table 2. Variation of $\mathrm{C}_{6}$-Fluorocarbon for preparation of specimens

\begin{tabular}{|c|l|}
\hline Sample Code & Recipe \\
\hline \multirow{2}{*}{ A } & RUCOSTAR EEE6: $40 \mathrm{~g} / 1$ \\
& RUCOLINK RCX: $15 \mathrm{~g} / 1$ \\
& RUCOFIN HSF: $10 \mathrm{~g} / 1$ \\
\hline & RUCOSTAR EEE6: $60 \mathrm{~g} / 1$ \\
BUCOLINK RCX: $15 \mathrm{~g} / 1$ \\
& RUCOFIN HSF: $10 \mathrm{~g} / 1$ \\
\hline & RUCOSTAR EEE6: $80 \mathrm{~g} / 1$ \\
CUCOLINK RCX: $15 \mathrm{~g} / 1$ \\
\end{tabular}


Table 3. Variation of cross linking agent for preparation of different specimens

\begin{tabular}{|c|c|}
\hline Sample Code & Recipe \\
\hline A1 & $\begin{array}{l}\text { RUCOSTAR EEE6: } 60 \mathrm{~g} / 1 \\
\text { RUCOLINK RCX: } 0 \mathrm{~g} / 1 \\
\text { RUCOFIN HSF: } 10 \mathrm{~g} / 1\end{array}$ \\
\hline B1 & $\begin{array}{l}\text { RUCOSTAR EEE6: } 60 \mathrm{~g} / 1 \\
\text { RUCOLINK RCX: } 05 \mathrm{~g} / 1 \\
\text { RUCOFIN HSF: } 10 \mathrm{~g} / 1\end{array}$ \\
\hline $\mathrm{C} 1$ & $\begin{array}{l}\text { RUCOSTAR EEE6: } 60 \mathrm{~g} / 1 \\
\text { RUCOLINK RCX: } 10 \mathrm{~g} / 1 \\
\text { RUCOFIN HSF: } 10 \mathrm{~g} / 1\end{array}$ \\
\hline D1 & $\begin{array}{l}\text { RUCOSTAR EEE6: } 60 \mathrm{~g} / 1 \\
\text { RUCOLINK RCX: } 15 \mathrm{~g} / 1 \\
\text { RUCOFIN HSF: } 10 \mathrm{~g} /\end{array}$ \\
\hline E1 & $\begin{array}{l}\text { RUCOSTAR EEE6: } 60 \mathrm{~g} / 1 \\
\text { RUCOLINK RCX: } 20 \mathrm{~g} / 1 \\
\text { RUCOFIN HSF: } 10 \mathrm{~g} / 1\end{array}$ \\
\hline
\end{tabular}

\subsection{Testing Methods}

\subsubsection{Tensile Strength Test}

Testing Method: ASTM D5034 (grab test)

Testing Condition: Temperature $=(20 \pm 2)^{\circ} \mathrm{C}$, Relative humidity $=(65 \pm 2) \%$

Sample size: $175 \mathrm{~mm} \times 100 \mathrm{~mm}$

Apparatus: Titan-Universal Strength Tester, Air compressor, Computer

\subsubsection{Spray Test}

Testing Method: AATCC -22

Testing Conditions: Temperature $=(20 \pm 2)^{\circ} \mathrm{C}$, Relative humidity $=(65 \pm 2) \%$

Sample size: $175 \mathrm{~mm} \times 100 \mathrm{~mm}$

Apparatus: Spray tester, Beaker, The chart (AATCC method 22)

\subsubsection{Water Vapor Permeability Test}

Testing Method: Cup Method

Testing Conditions: Temperature $=(20 \pm 2){ }^{\circ} \mathrm{C}$, Relative humidity $=(65 \pm 2) \%$

Sample size: $175 \mathrm{~mm} \times 100 \mathrm{~mm}$

Apparatus: Aluminum cup, Beaker, Incubator, Electrical balance

\subsubsection{Moisture Regain Test}

Testing method: ASTM D2495 (oven dry)

Testing condition: Temperature $=(105 \pm 2)^{\circ} \mathrm{C}$, Relative humidity $=(65 \pm 2) \%$

Sample size: $175 \mathrm{~mm} \times 100 \mathrm{~mm}$

Apparatus: Incubator, Electrical balance

\section{Result and Discussion}

\subsection{Effect of $\mathrm{C}_{6}$-Fluorocarbon Variation on $\mathbf{1 0 0 \%}$ Viscose Woven Fabric}

In this work, tensile strength test (ASTM D5034), spray test (AATCC-22), water vapor permeability test (cup method) and moisture regain test (ASTM D2495 oven dry method) were investigated. Each result will be analyzed and discuss in below.

\subsubsection{Tensile Strength Test for $\mathrm{C}_{6}$-Fluorocarbon Variation}

The tensile strength test determines the strength of the fabric. ASTM D5034 method was used for the test.

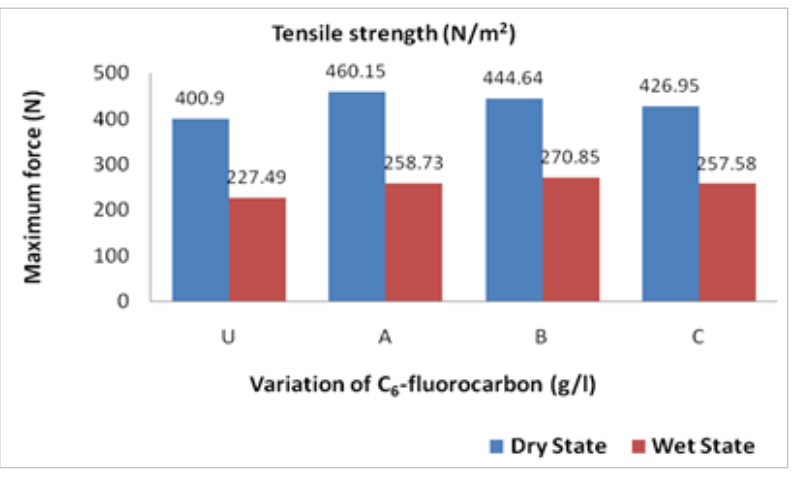

Figure 2. Tensile strength test for dry and wet viscose (for warp direction) fabric with $\mathrm{C}_{6}$-fluorocarbon

The above graph shows that the result of tensile strength test for dry and wet viscose warp fabric with variation of $\mathrm{C}_{6}$-fluorocarbon. There is a difference between treated and untreated viscose. Initially, untreated viscose has dry strengths of $400.90 \mathrm{~N}$. After applying water repellent finish, the strength of viscose was increased. In dry state, A demonstrates highest value and the $\mathrm{C}$ demonstrates lowest value. On the other hand, the result of tensile strength test for wet viscose warp fabric with $\mathrm{C}_{6}$-fluorocarbon indicates that untreated viscose has wet strength of $227.49 \mathrm{~N}$. After applying water repellent finish, the strength of viscose was gradually increased. The significant changes have been observed for B $(60 \mathrm{~g} / 1)$. It shows better wet strength at about $270.85 \mathrm{~N}$. In case of higher concentration of $\mathrm{C}_{6}$-fluorocarbon, the tensile strength decreases. This is due to the fact that, water repellent chemicals form cross link with viscose free O-H group in the amorphous region, it makes stiff of the viscose fabric. Cross linking reaction is done mainly in acidic condition which is also responsible for the reduction of tensile strength of viscose fabric. 


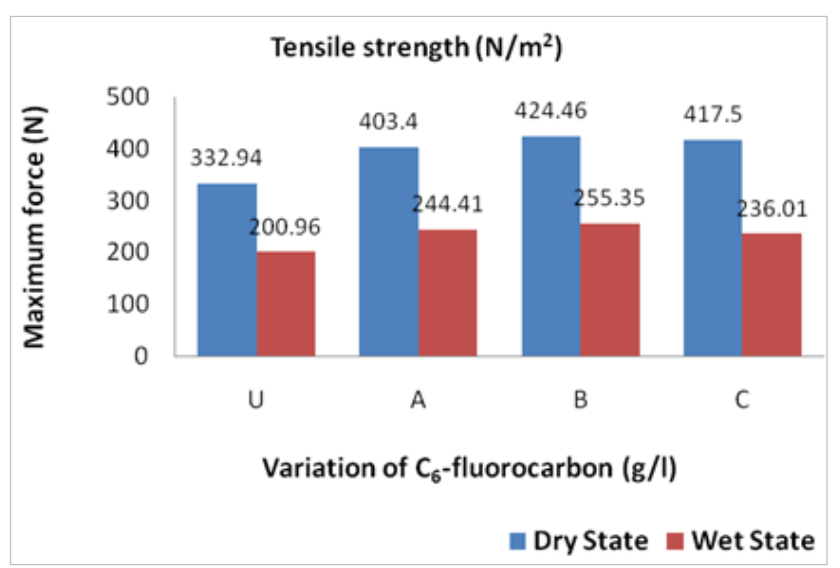

Figure 3. Tensile strength test for dry and wet viscose (for weft direction) fabric with $\mathrm{C}_{6}$-fluorocarbon

The above table shows that the results of tensile strength tests for dry and wet viscose weft fabric with different amount of $\mathrm{C}_{6}$-fluorocarbon. There is a difference between treated and untreated viscose. Initially, untreated viscose has dry strength of $332.94 \mathrm{~N}$. After applying water repellent finish, the strength of viscose was increased. Sample -B provides the highest value and sample A provides lowest value. On the other hand, the result of tensile strength tests for wet viscose weft fabric with $\mathrm{C}_{6}$-fluorocarbon shows difference between treated and untreated viscose. Initially, untreated viscose has wet strength of $200.96 \mathrm{~N}$. After applying water repellent finish, the strength of viscose was increased. Here B shows the highest value and $\mathrm{C}$ shows the lowest value subsequently. In case of higher concentration of $\mathrm{C}_{6}$-fluorocarbon, the tensile strength decreases. This is due to the fact that, water repellent chemicals form cross link with viscose free $\mathrm{O}-\mathrm{H}$ group in the amorphous region, it makes stiff of the viscose fabric. Cross linking reaction is done mainly in acidic condition which is also responsible for the reduction of tensile strength of viscose fabric.

\subsubsection{Spray Test for $\mathrm{C}_{6}$-Fluorocarbon Variation}

The spray test determines the water resistance of the fabric. AATCC-22 method was used for the test.

Table 4. Effect of $\mathrm{C}_{6}$-fluorocarbon variation on spray test

\begin{tabular}{|c|c|c|c|}
\hline Testing method & A & B & C \\
\hline Spray Test Ratings(AATCC-22) & 80 & 90 & 70 \\
\hline Spray Test Ratings(ISO) & 3 & 4 & 2 \\
\hline
\end{tabular}

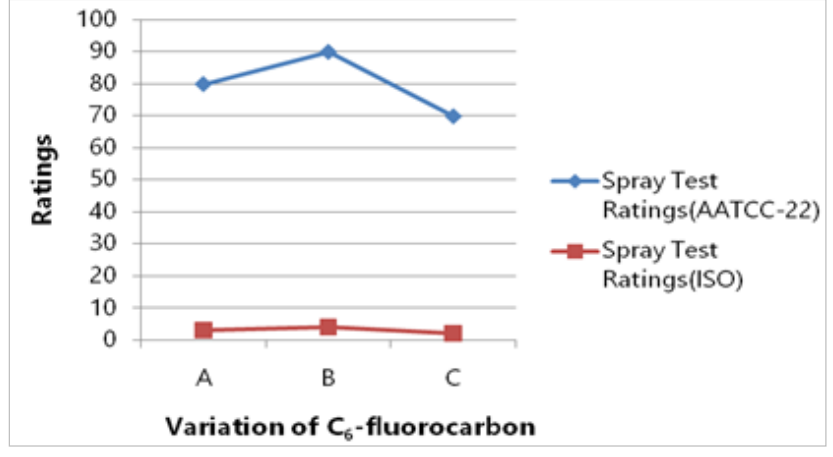

Figure 4. Spray test ratings with Variation of $\mathrm{C}_{6}$-fluorocarbon

The above figure shows that the results of spray test with variation of $\mathrm{C}_{6}$-fluorocarbon. The result of the spray test for $\mathrm{A}, \mathrm{B}$ and $\mathrm{C}$ are 80,90 and 70 , respectively. It has shown that the highest value existed in $\mathrm{B}$ and the lower value in $\mathrm{A}$ and C. $\mathrm{C}_{6}$-fluorocarbon is a coating material. In the increasing amount of $\mathrm{C}_{6}$-fluorocarbon the coated properties increased and at certain limit, water resistance properties decreased due. At this case, it shows lower amount of value.

\subsubsection{Water Vapor Permeability Test for $\mathrm{C}_{6}$-Fluorocarbon Variation}

Table 5. The testing results of water vapor permeability test with variation of $\mathrm{C}_{6}$-fluorocarbon

\begin{tabular}{|c|c|c|}
\hline Sample Code & Name of Sample & Value $\left(\mathbf{g m} / \mathbf{m}^{\mathbf{2}} / \mathbf{d a y}\right)$ \\
\hline A & Sample with EEE6-40 g/1 & 923.992 \\
\hline B & Sample with EEE6-60 g/1 & 1321.678 \\
\hline C & Sample with EEE6-80 g/1 & 1581.874 \\
\hline
\end{tabular}

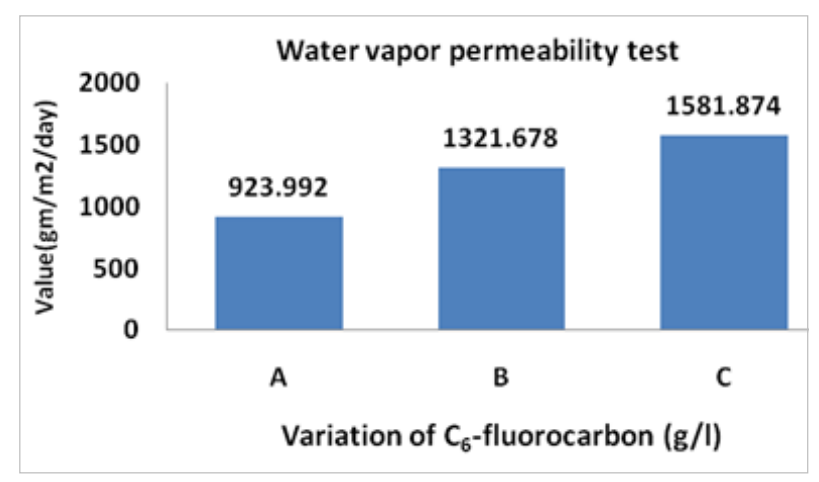

Figure 5. Water vapor permeability test with variation of $\mathrm{C}_{6}$-fluorocarbon 
The above figure shows that the results of water vapor permeability test with variation of $\mathrm{C}_{6}$-fluorocarbon. The result of sample-A B and C are 923.992, 1321.678, and $1581.874\left(\mathrm{gm} / \mathrm{m}^{2} /\right.$ day $)$ respectively. It has shown that the highest value existed in Cand the lowest value in $\mathrm{A}$. In the C highest amount $\{80(\mathrm{~g} / \mathrm{l})\}$ of $\mathrm{C}_{6}$-fluorocarbon is obtained. At this causes it shows higher amount of value. After increasing the concentration of $\mathrm{C}_{6}$-fluorocarbon, the thin layer formation the fabric surface occurs and formation of cross-linking networks after finishing creates higher amount of water vapor permeability.

\subsubsection{Moisture Regain Test}

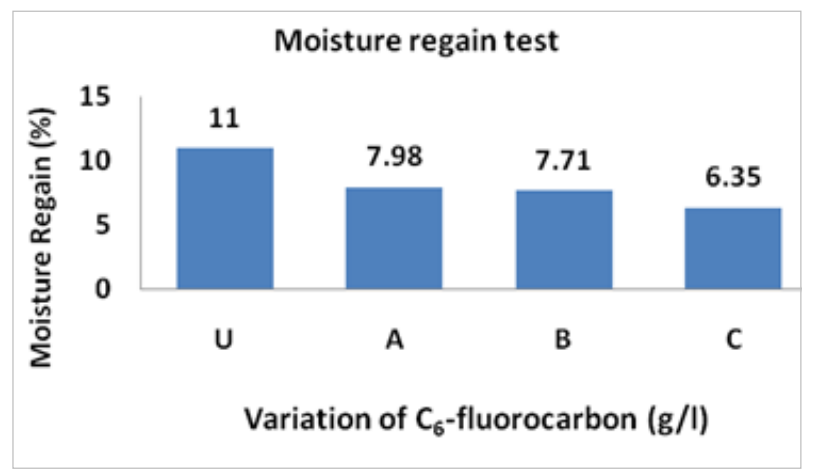

Figure 6. Moisture regain test for $\mathrm{C}_{6}$-fluorocarbon (EEE6)

The above graph shows that the results of moisture regain test with variation of $\mathrm{C}_{6}$-fluorocarbon. The result of sample-untreated and A, B, C are 11, 7.98, 7.71 and 6.35 percent respectively. It has shown that the highest value existed in sample-untreated and the lowest value in C. In the increasing amount of $\mathrm{C}_{6}$-fluorocarbon the moisture regain percentage decreased. This is due to the fact that, after applying $\mathrm{C}_{6}$-fluorocarbon (water repellent finishes) on the fabric surface, chemical deposition on the fabric surface occurs and creates barrier for moisture regain $\%$.

\subsection{Effect of Cross-Linking Agent (RCX) Variation on 100 \% Viscose Woven Fabric}

In this project work tensile strength test (ASTM D5034), spray test (AATCC - 22), water vapor permeability test (cup method) and moisture regain test (ASTM D2495 oven dry method) were investigated. Each result will be analyzed and discuss in below.

\subsubsection{Tensile Strength Test for Cross-Linking Agent Variation}

The tensile strength test determines the strength of the fabric. ASTM D5034 method was used for the test.

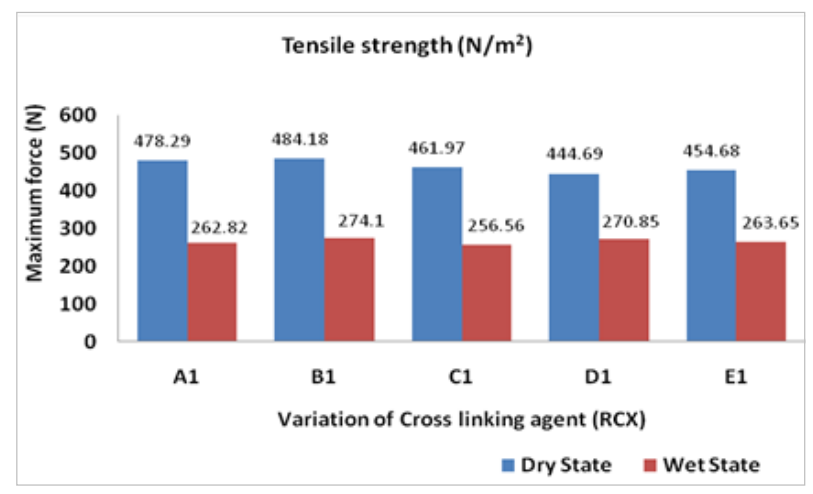

Figure 7. Tensile Strength test for dry and wet viscose (for warp direction) fabric with cross- linking agent

The above figure shows that the result of tensile strength tests for dry and wet viscose warp fabric with variation of cross-linking agent (RCX). After applying cross-linking agent (RCX), it was observed about different values for each treated sample where B1 shows the highest value to tear and D1 shows the lowest value. On the other hand, for the result of tensile strength tests for wet viscose warp fabric with cross-linking agent (RCX), we got different values for each treated sample where B1 provides the highest value to tear and $\mathrm{C} 1$ provides the lowest value.

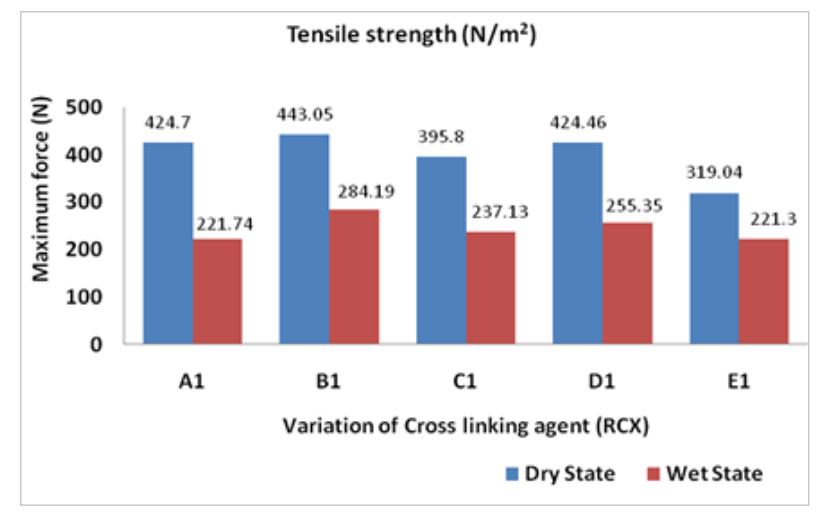

Figure 8. Tensile Strength test for dry and wet viscose (for weft direction) fabric with cross- linking agent

The above figure shows that the result of tensile strength tests for dry and wet viscose weft fabric with variation of cross-linking agent (RCX). After applying cross-linking agent (RCX), we got different values for each treated sample where B1 gets the highest value and E1 gets the lowest value. On the other hand, the result of tensile strength tests for wet viscose weft fabric with cross-linking agent (RCX), we got different value for each treated sample where sample-B1 shows the highest value to tear and sample-E1 shows the lowest value. 


\subsubsection{Spray Test for Cross Linking Agent (RCX) Variation}

The spray test determines the water resistance of the fabric.AATCC-22 method was used for the test.

Table 2. Effect of cross linking agent variation on spray test

\begin{tabular}{|c|c|c|c|c|c|}
\hline Testing method & A1 & B1 & C1 & D1 & E1 \\
\hline Spray Test Ratings(AATCC-22) & 70 & 80 & 80 & 90 & 50 \\
\hline Spray Test Ratings(ISO) & 2 & 3 & 3 & 4 & 1 \\
\hline
\end{tabular}

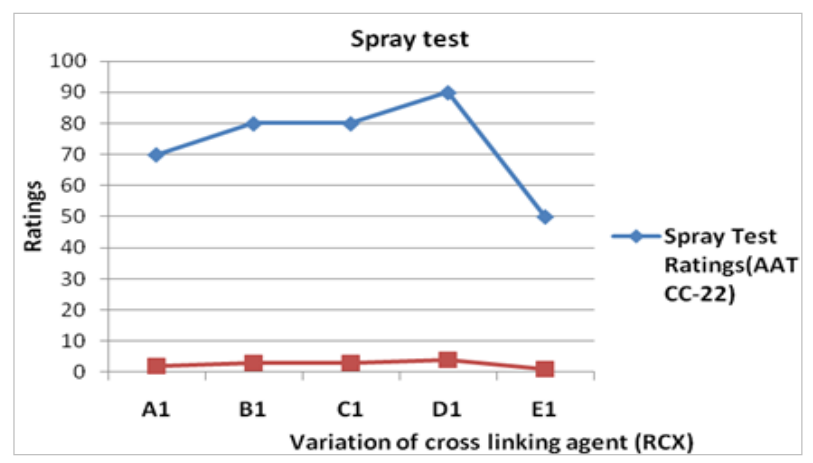

Figure 9. Spray test ratings with variation of RCX

The above figure shows the result of spray test with variation of cross-linking agent (RCX). The result of different samples with Code A1, B1, C1, D1, E1 are 70, 80, $80,90,50$ respectively.It has shown that the highest value existed in sample-D1 and the lowest value in sample-E1.RCX is a coating material. In the increasing amount of RCX the coated properties will be increased. In D1 higher amount of RCX was used. At this case, it shows higher amount of value. This is due to the fact that after increasing the concentration of cross linking agent, it modulates the fabric surface, that's why at higher amount of concentration; it provides lowest value regarding this test.

\subsubsection{Water Vapor Permeability Test for Cross-Linking Agent Variation}

Table 6. The testing results of water vapor permeability test with variation of RCX

\begin{tabular}{|c|c|c|}
\hline Sample Code & Name of Sample & Value $\left.\mathbf{( g m} / \mathbf{m}^{\mathbf{2}} / \mathbf{h}\right)$ \\
\hline A1 & Sample with RCX 0 g/1 & 107.888 \\
\hline B1 & Sample with RCX 5 g/1 & 578.049 \\
\hline C1 & Sample with RCX 10g/1 & 174.44 \\
\hline D1 & Sample with RCX15 g/1 & 1321.678 \\
\hline & Sample with RCX 20 g/1 & 140.44 \\
\hline
\end{tabular}

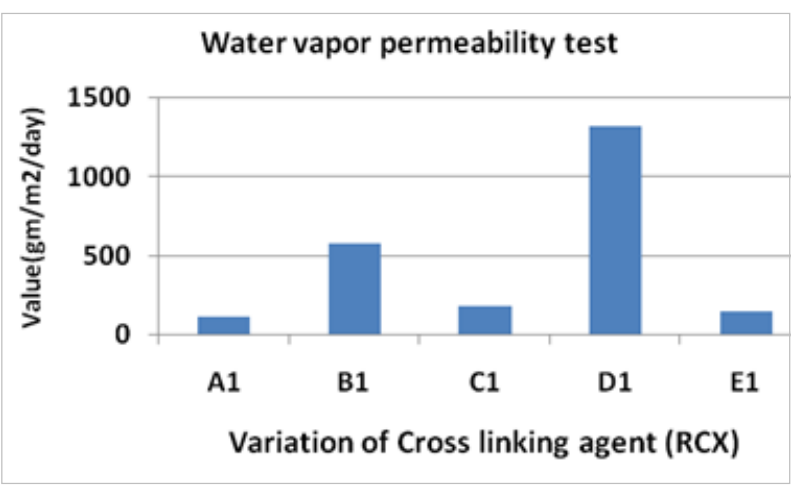

Figure 10. Water vapor permeability test with variation of RCX

The above graph shows that the results of water vapor permeability test with variation of RCX. The result of sample-A1, B1, C1, D1 and E1 are 107.888, 578.049, $174.44,1321.678$ and $140.44\left(\mathrm{gm} / \mathrm{m}^{2} /\right.$ day) respectively. It has shown that the highest value existed in sample-D1 and the lowest value in A1. In the D1, higher amount of RCX was used. At this case, it shows higher amount of value.

\subsubsection{Moisture Regain Test for Cross-Linking Agent} (RCX) Variation

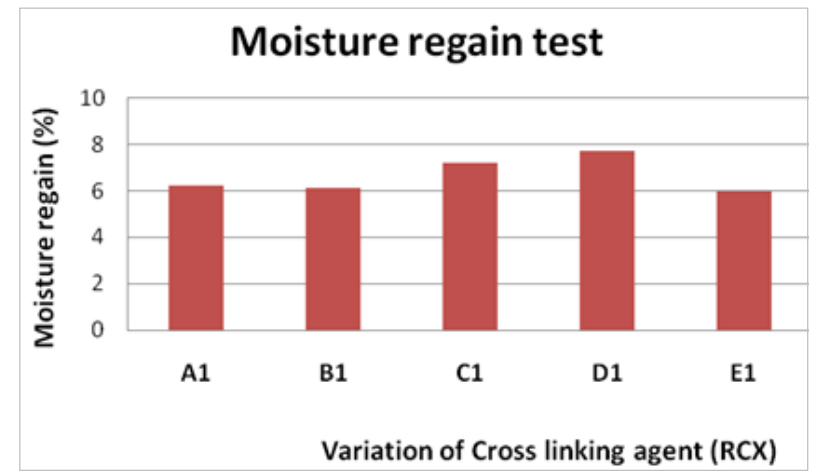

Figure 11. Moisture regain test for different cross linking agents RCX

The above figure shows the results of moisture regain test with variation of cross linking agent $\mathrm{RCX}$. The result of sample- A1, B1, C1, D1 and E1 are 6.25, 6.15, 7.23, 7.71, 6.00 percent respectively. It has shown that, the highest value existed in D1 and the lowest value in B1. Due to the increasing amount of RCX, the moisture regain percentage also decreased in subsequent process. 


\section{Conclusions}

Viscose has poor wet strength due to higher moisture regain. The most desired property of viscose for this research was tensile strength and it was improved to a large scale by applying water repellent finishes. Elongation (dry and wet) of viscose was improved after applying the water repellent finishes. Here two types of variation along with eight recipes were used.

For $\mathrm{C}_{6}$-fluorocarbon variation, sample $\mathrm{A}$ was treated with $\mathrm{C}_{6}$-fluorocarbon $40 \mathrm{~g} / \mathrm{l}$, cross linking agent $15 \mathrm{~g} / \mathrm{l}$ and softener $10 \mathrm{~g} / \mathrm{l}$; for $\mathrm{B}$, it was treated with $\mathrm{C}_{6}$-fluorocarbon $60 \mathrm{~g} / \mathrm{l}$, cross linking agent $15 \mathrm{~g} / \mathrm{l}$ and softener $10 \mathrm{~g} / \mathrm{l}$; for $\mathrm{C}$ it was treated with $\mathrm{C}_{6}$-fluorocarbon $80 \mathrm{~g} / \mathrm{l}$, cross linking agent $15 \mathrm{~g} / 1$ and softener $10 \mathrm{~g} / \mathrm{l}$. Different tests were performed to evaluate the performance and found highest wet tensile strength on $B$ and lowest wet tensile strength on C. But in the dry state sample- A also showed the highest value.

For cross linking agent variation, sample A1 was treated $\mathrm{C}_{6}$-fluorocarbon $60 \mathrm{~g} / 1$, cross linking agent $0 \mathrm{~g} / \mathrm{l}$ and softener $10 \mathrm{~g} / \mathrm{l}$; B1 was treated $\mathrm{C}_{6}$-fluorocarbon $60 \mathrm{~g} / \mathrm{l}$, cross linking agent $05 \mathrm{~g} / 1$ and softener $10 \mathrm{~g} / 1$; $\mathrm{C} 1$ was treated with $\mathrm{C}_{6}$-fluorocarbon $60 \mathrm{~g} / 1$, cross linking agent 10 $\mathrm{g} / 1$ and softener $10 \mathrm{~g} / \mathrm{l}$; D1 was treated $\mathrm{C}_{6}$-fluorocarbon 60 $\mathrm{g} / \mathrm{l}$, cross linking agent $15 \mathrm{~g} / 1$ and softener $10 \mathrm{~g} / \mathrm{l}$; E1 was treated $\mathrm{C}_{6}$-fluorocarbon $60 \mathrm{~g} / \mathrm{l}$, cross linking agent $20 \mathrm{~g} / \mathrm{l}$ and softener $10 \mathrm{~g} / \mathrm{l}$. Here it showed highest wet tensile strength on B1 and lowest wet tensile strength on $\mathrm{C} 1$.

Based on these tests, it can be concluded that viscose fabric with sample-B1 (treated with $\mathrm{C}_{6}$-fluorocarbon $60 \mathrm{~g} / 1$, cross linking agent $05 \mathrm{~g} / \mathrm{l}$ and softener $10 \mathrm{~g} / \mathrm{l}$ ) is suitable for tensile strength.

\section{Conflict of Interest}

The authors have declared no conflict of interest.

\section{Compliance with Ethics Requirements}

This article does not contain any studies with human or animal subjects performed by any of the authors.

\section{Acknowledgements}

The authors gratefully acknowledge physical testing and analytical laboratory of Department of Textile Engineering, Mawlana Bhashani Science and Technology University for technical support of this work.

\section{REFERENCES}

[1] Lotens, W. A., Havenith, G. (2007) Effects of moisture absorption in clothing on the human heat balance. Ergonomics, 38 (6), 1092-1113.

[2] Asif, A.K.M.A.H., Hasan, M.Z. (2018) Application of Nanotechnology in Modern Textiles: A Review. International Journal of Current Engineering and Technology, 8(2), 227-231.

[3] Jun, L., Yehu, L., Xiaohui, L. (2012) Effect of relative humidity coupled with air gap on heat transfer of flame-resistant fabrics exposed to flash fires. Textile Research Journal, 82(12), 1235-1243.

[4] Liu, Y. (2013) Effect of the Brownstone Moisture Content at Application Time of a Water Repellent Treatment. (Master's Thesis) University of Pennsylvania, Philadelphia, PA.

[5] Suman, P., Rajkumari, J. (2014) Comfort and Mechanical Properties of Cotton and Cotton Blended Knitted Khadi Fabrics. Stud Home Com Sci, 8(2-3), 69-74.

[6] Iqbal, M.S., Mamun, M.A.A., Siddiquee, M.A.B., Asif, A.K.M.A.H. (2016) Effect of Finishing Machine Parameters on Dimensional Stability of Single Lacoste Cotton Knitted Fabric. Advances in Materials, 5(5), 35-43.

[7] Rahman, M., Asif, A.K.M.A.H., Siddiquee, M.A.B. and Rokonuzzaman, M. (2014) Effect of shade percentage on various properties of cotton knitted fabric dyed with reactive dyes. International Journal of Research in Engineering and Technology, 3(2), 339-343.

[8] Sousa, D.J., Cheatham, C., Wittbrodt, M. (2014) The effects of a moisture-wicking fabric shirt on the physiological and perceptual responses during acute exercise in the heat. Applied Ergonomics, 45(6), 1447-1453.

[9] Mamun, M.A.A., Rahman, M., Asif, A.K.M.A.H., Sarkar, P (2014) Effect of Dyeing Parameters on Color Strength and Fastness Properties of Cotton Knitted Fabric Dyed with Direct Dyes. International Journal of Current Engineering and Technology, 4(2), $1068-1072$.

[10] Dai, X. Q., Imamura, R., Liu, G.L., Zhou, F.P., (2008) Effect of moisture transport on microclimate under T-shirts. European Journal of Applied Physiology, 104 (2), 337-340.

[11] Siddiquee, M.A.B., Asif, A.K.M.A.H., Khan, R. H., Anwar, M. T., Islam, M. S. and Noushin, N. (2016) Study on the Effect of Dyeing and Finishing Parameters on Cotton Knitted Two Thread Fleece Fabric and 1x1 Rib Fabric. Science Research, 4(1), 7-10.

[12] Fu, M., Weng, W., Han, X.F. (2013) Effects of moisture transfer and condensation in protective clothing based on thermal manikin experiment in fire environment. Procedia Engineering, 62, 760-768; 
[13] Dutta P. K., Dutta, J., Tripathi, V.S. (2014) Chitin and chitosan: Chemistry, properties and application. Journal of Scientific \& Industrial Research, vol.63, pp. 20-31.

[14] Rokonuzzaman, M., Mamun, M.A.A., Asif, A.K.M.A.H. (2017) Effect of heat setting conditions on the quality of yarn. Frontiers in Science, 7(3), 46-49.

[15] Cimilli, S., Nergis, B., Candan, C., Özdemir, M. (2010) A Comparative Study of Some Comfort-Related Properties of Socks of Different Fiber Types. Textile Research Journal, 80(10), pp. $948-957$.

[16] Gun, A.D. (2011) Dimensional, Physical and Thermal Properties of Plain Knitted Fabrics Made From 50/50 Blend of Modal Viscose Fiber in Microfiber Form With Cotton Fiber. Fibers and Polymers, 12 (8), pp. $1083-1090$.

[17] Razzaque, A., Saha, J., Asif, A.K.M.A.H., Rahman, M. (2015) Influence of Pin Spacer on Yarn Quality in a Ring Frame. International Journal of Current Engineering and Technology, 5(4), 2380 -2382.
[18] Erdumlu, N., Ozipek, B. (2008) Investigation of Regenerated Bamboo Fibre and Yarn Characteristics. Fibres\& Textiles in Eastern Europe, 16 (4), pp. 43 - 47.

[19] Männer, J., Schuster, K.C., Suchomel, F., Gürtler, A., Firgo, H. (2004) Higher Performance with Natural Intelligence. LenzingerBerichte, 83 , pp. $99-110$.

[20] Hasan, M., Z., Asif, A. K. M. A. H., Mamun M.A.A., Sarker, P., Iqbal, S. M. F. (2018) Effect of Resin Finish for Crinkle Appearance on Bending and Tensile Properties of Denim Fabrics. International Journal of Textile Science, 7 (3), 75-81.

[21] Dhamija, S., Chopra, M. (2007) Tearing Strength of Cotton Fabrics in Relation to Certain Process and Loom Parameters. Indian Journal of Fibers \& Textile Research, 32 (4), pp. 439 -445 .

[22] Kullman, R.M., Graham, J.R.C.O., Ruppenicker, G.F. (1981) Air permeability of Fabrics made from unique and Conventional yarns. Textile Research Journal, 51 (12), pp. $781-786$. 